\title{
Modern Technologies for Resolving Conflicts within an Organization
}

\author{
Dublenkova Svetlana, Anoshin Konstantin, Sokolovskaia Irina \\ Russian State Social University, Moscow, Russia
}

\begin{abstract}
ANNOTATION
Research problem and degree of the research: Today, conflicts take place in all organizations. Current realities do not allow enterprises to exist in a comfort zone without internal obstacles; otherwise, an institution simply will not survive. This article is based on both the positive meaning of conflict and on an analysis of the negative aspects of conflict, specifically regarding modern technologies which allow resolving conflict contradictions in some cases or to avoid it completely in others, for example, when there are rudiments of their maturation.
\end{abstract}

Purpose of the article: to analyze modern technologies for resolving conflicts in an organization.

Subject of the article: Modern technologies for conflict resolution.

There are quite a few types of intra-organizational conflicts, but we will focus on the contradictions that arise in teams. The article analyzes the technologies of conflict resolution in two projections: in resolving a conflict that has already arisen and in its prevention.

Research methods: The following research methods were used:

- theoretical analysis of scientific sources;

- analysis of foreign conflict resolution techniques.

Modern conflict resolution technologies are focused on the constructive participation of all parties to the conflict. At the same time, the managers' actions play a certain role, as they are endowed with exclusive functions for managing conflicts within their department and they are personally responsible for the situation in the team.

Of course, it is necessary to apply preventive methods to prevent contradictions. If nevertheless the conflict emerged for various reasons: either the contradiction was implicit, or this issue was not given due attention, it is necessary to be guided by slightly different methods. In any case, the resolution of intra-organizational conflicts in a team should be focused on the psychological aspect of employees. It is necessary to work with each employee, paying attention to his or her needs and interests.

Conclusion. This article examined the main modern methods for preventing and resolving conflicts, used in many organizations. The theoretical aspects of intra-organizational conflicts, including the cause of the conflict, its' structure and typology were considered. The article was also focused on the typical managers' mistakes when resolving conflicts.

Key words: corporate conflict, resolution technologies, managerial impact, mediation.

\section{INTRODUCTION}

Research problem and degree of the research: Today, conflicts take place in all organizations. Current realities do not allow enterprises to exist in a comfort zone without internal obstacles; otherwise, an institution simply will not survive. This article is based on both the positive meaning of conflict and on an analysis of the negative aspects of conflict, specifically regarding modern technologies which allow resolving conflict contradictions in some cases or to avoid it completely in others, for example, when there are rudiments of their maturation.

Purpose of the article: to analyze modern technologies for resolving conflicts in an organization.

Subject of the article: Modern technologies for conflict resolution.

There are quite a few types of intra-organizational conflict, but we will focus on the contradictions that arise in teams. The article analyzes the technologies of conflict resolution in two projections: in resolving a conflict that has already arisen, and in its prevention.

\section{Research methods:}

The following research methods were used:

- theoretical analysis of scientific sources;

- analysis of foreign conflict resolution techniques. 


\section{RESEARCH RESULTS AND DISCUSSION}

Organizational conflict, or workplace conflict, is a state of discord caused by the actual or perceived opposition of needs, values and interests between people working together (Organizational conflict, 2021). There are different forms of conflicts in organizations. There is the inevitable clash between formal authority and subordinates. There are also disputes over how revenues should be divided, how the work should be done and how long and hard people should work.

The structure of an intra-organizational conflict is understood as the whole set of parts of the conflict, its elements, connections and relationships.

The structure of the conflict is distinguished as:

- parties involved (employees of the organization);

- an incident (a provoking action that may lead to negative consequences);

- subject (reason for the controversy).

Dynamics, that is, the life cycle of a conflict consists of the following stages (An, 2014):

1. pre-conflict situation;

2. incident;

3. escalation of the conflict (growth);

4. culmination;

5. conflict resolution;

6. negotiations;

7. post-conflict syndrome.

Conflict prevention - activities to create and strengthen such living conditions in which the possibility of conflicts is excluded (Abuzyarova, 2017).

In order to study intra-organizational conflicts, let us consider their typology:

Vertical conflict. This type of contradiction is associated with the levels of management in the organization, i.e., it's a problem that arises between departments that are not equal in position, where one is subordinate to the other.

Horizontal conflict. This is a type of conflict in which non-subordinate employees or departments are involved. For example, these can be divisions that perform the same functions, which are subordinate to a higher division, but lead different sections.

Linear-functional conflict. This contradiction arises between line managers or specialists who are approximately in the same positions, that is, in essence, this is a horizontal type of conflict, but the peculiarity lies in the fact that the resolution of this conflict is focused on improving relations between the conflicting parties.

Role conflict. This type of conflict is associated with the employee's understanding of the ambiguity of the role assigned to him or her. That is, if an employee is entrusted with a greater amount of work, he or she may perceive this as a desire of management to get rid of them, and not as the fact that they see the employee as a promising professional and load them up in order to advance them on the career ladder in the near future.

Conflict resolution technologies - methods and resources helpful to the elimination of disputes. 
Technologies for preventing an emerging conflict focus on eliminating disputes and their future consequences, that is, their task is precisely to prevent conflict, and to resolve it at the pre-conflict stage. The psychological aspect of the personnel is of great importance today.

Competent leaders will use the following technologies to prevent possible conflict:

Prescribing the basic elements of corporate culture in local acts of the organization and applying them in practice. The use of a dress code, the universalization of workplaces, and adherence to common goals will undoubtedly reduce conflict risks, as the level of both discipline and self-discipline increases. In such conditions, a person will feel like a part of a big deal, the differences between people will be minimal, that is, there will be no basis for conflict as such.

Introduction of the department for the selection and support of employees or a specialist in personnel adaptation to the organization. First of all, the work of these staff units will make it possible to select not only qualified professionals, but also less conflicted people. Also, this concept is especially relevant for newly hired employees who need to join the organization. It should be said that many public and private institutions have a mentoring institute, which allows newcomers to adapt to all processes of the organization's functioning.

Delimitation of the workspace. Too many people should not be put in one office, no matter how large the room is. A larger number of employees in one room will be accompanied, first, by a decrease in efficiency, and, second, by an increase in conflict.

Elaboration of a disciplinary action system. Here we are talking about the analysis of the rewards and penalties methods used in the organization. After researching these methods, you need to understand what can be refused or added. First of all, it would make sense to prescribe in more detail the cases of the disciplinary sanctions application (reprimand, severe reprimand, dismissal and etc.) both in the general local acts of the organization and in the job descriptions of employees. Next, you need to study the incentive system, which is also advisable to bring on line for each staff unit.

One of the most advanced conflict prevention technologies in an organization is the use of the psychologist services, either in-house or outsourced. Western countries increasingly resort to using the services of a remote psychologist, who is always in touch and ready to help an employee at any time.

If the pre-conflict stage has turned into a conflict stage, then, in addition to the technologies discussed above, it is necessary to be guided by the following:

Operative manager's intervention in a conflict contradiction, since the conflict can go beyond the organization and, first, lead to the participation of supervising state institutions in this issue, and secondly, damage the reputation of the organization.

Taking measures to eliminate or remove the causes of the conflict. Even if the cause of the conflict is the employee him or herself, then the head or responsible department needs to work out the issue of minimizing the employee's influence on the rest of the team. Here the employee may be transferred to another position in another department or registered for remote work.

Reducing psychological tension. For example, you could organize a joint event that can eliminate disagreements between people. However, of course, it should be kept in mind that corporate events could either eliminate or aggravate the conflict.

Taking into account the employees' interests and suggestions on various issues. Undoubtedly, the impact of staff will be maximized when their views are taken into account. Various discussions of problems 
and proposals for their solution will allow the team to get closer. At the same time, as practice shows, managers make mistakes when using the above technologies.

First, many managers try to resolve an arisen dispute without analyzing the problem. Basically, this is natural, since the management is interested in the prompt resolution of the issue, they pay less attention to diagnostics than they should. This position is incorrect from the point of view that for a final and constructive resolution of the conflict, it is necessary to conduct a full analysis, to find out the motives of the conflicting parties, their goals and objectives.

Second, some leaders simply freeze the conflict. On the one hand, this concept is sometimes appropriate, as it allows opposing parties to cool down. On the other hand, the root of the conflict is not eradicated and can lead to greater escalation in the future.

Third, managers can delay the problem's resolution. Intergroup conflicts can often turn into interpersonal and intrapersonal conflicts over time. If exhaustive measures are not taken in time, even very successful methods of resolving intra-organizational conflicts will not help to resolve other contradictions that have arisen on their basis.

Fourth, shifting the responsibility for resolving the problem onto others. In order to save their own time, managers either use the services of a mediator or delegate authority to resolve the conflict to another employee of the organization. It should be noted here that very often only the leader can resolve the contradiction that has arisen. There is also no guarantee that the appointed mediator will be interested in resolving the controversy. It is far from a fact that he will be able to carry out high-quality diagnostics of problems and offer a constructive solution.

Finally, the generalization of the conflict. The essence of this leader's mistake boils down to the fact that if you do not start taking action in time, in the end, the conflicting parties can attract more significant parties as allies, and in this case the manager will no longer be able to resolve the problem on his own.

\section{DISCUSSION}

Modern conflict resolution technologies are focused on the constructive participation of all parties to the conflict. At the same time, managers' actions play a certain role, as they are endowed with exclusive functions for managing conflicts within their department and are personally responsible for the situation in the team.

Of course, it is necessary to apply preventive methods to prevent contradictions. If nevertheless the conflict emerged for whatever reason - either the contradiction was implicit, or this issue was not given due attention - it is necessary to be guided by slightly different methods. In any case, the resolution of intra-organizational conflicts in a team should be focused on the psychological aspect of employees. It is necessary to work with each employee, paying attention to his or her needs and interests.

\section{CONCLUSION}

This article examined the main modern methods for preventing and resolving conflicts, used in many organizations. The theoretical aspects of intra-organizational conflicts, including the cause of the conflict, its structure and typology were considered. The article also focused on the typical managers' mistakes when resolving conflicts. 


\section{REFERENCES}

1. Абузярова, Я. Э. (2017). Решение проблем управления конфликтами в современных организациях. Научные записки молодых исследователей, 3, 55-58.

2. Алексеев, О. А. (2012). Конфликтология и управление. Теоретические основы, аналитическая модель, практическое значение. Academic Publishing house IP Er Media. Saratov

3. An, Y. N. (2014). The classification of internal organizational conflict and management methods. Наука о человеке: гуманитарные исследования, 11-18. https://cyberleninka.ru/article/n/klassifikatsiya-vnutriorganizatsionnyh-konfliktov-i-metodov-upravleniya-imi/viewer

4. Ангараева, Е. Н., \& Кузнецова, Н. В. (2018). Совершенствование системы найма и отбора персонала на основе внедрения технологии оценки талантов. Human Progress, 4(6), 1-17. [Электронный ресурc] URL: http://progress-human.com/images/2018/Tom4 6/Angaraeva.pdf, свободный. Загл. с экрана. - Яз. рус., англ.

5. Bercovitch, J. (2014). Conflict and conflict management in organizations: a framework for analysis. Hong Kong Journal of Public Administration, 5(2), 104-123.

6. Гуня, А. Н., Дакснер, М., Кёлер, Я., Тенов, Т. 3., Чеченов, А. М., \& Шогенов, М. 3. (2013). Конфликты и развитие: введение в методологию и методы изучения. Nalchik. KBGU. ISBN 978-5-7558-0526-1.

7. Conflict at Workplace - Why Conflict Should be Avoided? (2021). Management study guide. [electronic resource]. Date of treatment: 25.04.2021. URL: https:/www.managementstudyguide.com/conflict-at-workplace.htm.

8. Conflict is the Stuff of Life. (2019). Conflict Resolution Network : [electronic resource]. Date of treatment: 23.04.2021. URL: https://www.crnhq.org/cr-kit/

9. Segal, J., Robinson, L., Smith, M. (2020). Conflict Resolution Skills Help Guide. [electronic resource]. Date of treatment: 26.04.2021. URL: https://www.helpguide.org/articles/relationships-communication/conflict-resolution-skills. $\underline{\mathrm{htm}}$

10. Година, О. В., Чижиков, Д. В., \& Самохина, Е. Е. (2018). Развитие социально-психологических технологий в управлении персоналом организации. Вестник Кемеровского государственного университета. Серия: Политические, социологические $u$ экономические науки, 4, 19-25.

11. Гринберг, Дж, (2002). Управление стрессом. СПб.: Питер,.

12. Кибанов, А. Я., Коновалова, В. Г., \& Белова, О. Л. (2013). Управление персоналом: теория и практика. Управление конфликтами и стрессами. Москва: Общество с ограниченной ответственностью «Проспект»

13. Мясницын, Р. В., \& Федорова, А. В. (2015). Современные технологии урегулирования конфликтов в организациях. Инновационная наука, 1(3), 252-256.

14. Oachesu, M. (2016). Conflict Management, a new challenge. Procedia Economics and Finance. 39, 807-814.

15. Organizational conflict. (2021). Wikipedia, the free encyclopedia : [electronic resource]. Date of treatment: 20.04.2021. URL: https://en.wikipedia.org/wiki/.

16. Петрова, Т. Н., \& Пясецкая, Е. Н. (2019). Проектный подход к формированию кадрового резерва. Политика, экономика $и$ инновации, 6(29), 123-127.

17. Reznikova, O. S. (2017). Conflict management in the organization. Problems of Economics and Management, 3, $15-23$.

18. Шарков, Ф.И., Сперанский, В. И. (2015). Общая конфликтология: учебник. Москва: Дашков и К.

19. Соловьева, М. Н. (2013). Влияние организационной культуры на разрешение конфликтов внутри организации. Экономика $u$ управление: анализ тенденций $u$ перспектив развития, 8, 156-160.

20. Strategies to avoid Conflicts at the Workplace. (2021). Management study guide: [electronic resource]. Date of treatment: 25.04.2021. URL: https:/www.managementstudyguide.com/strategies-to-avoid-conflicts-at-work.htm

21. Цыганкова, Е. А. (2013). Потенциал группового влияния на регулирование внутриорганизационных конфликтов. Социально-гуманитарные знания, 12, 13-16.

22. Водопьянова, Н., \& Старченкова, Е. (2021). Синдром выгорания. Диагностика и профилактика 3-е изд., испр. и доп. Практическое пособие. Litres.

23. Вест, А. А., \& Фёдорова, А. В. (2015). Риски и конфликты в современных организациях: проблемы и песрспективы управления. Инновационная наука, 3, 55-59.

24. Живага, А. Ю. (2019). Управление конфликтами и стрессами в организации: учебное пособие. ЮжноСахалинск: СахГУ. 


\title{
Современные внутриорганизационные технологии разрешения конфликтов
}

\author{
Дубленкова Светлана, Аношин Константин, Соколовская Ирина \\ ФГБОУ ВО «Российский государственный социальньй университет», Москва, Россия
}

\begin{abstract}
АННОТАЦИЯ
Проблемы и содержание исследования. На сегодняшний день не существует ни одной организации, в которой бы не происходили конфликты. Текущие реалии не позволяют предприятиям находиться в зоне комфорта и не иметь внутренних преткновений, в противном случае, учреждение банально не выживет. В статье идет речь не только о позитивном значении конфликта, но также анализируются и негативные позиции конфликта, с упором на современные технологии, позволяющие в одних случаях нивелировать конфликтные противоречия, в других их
\end{abstract} полностью избегать, когда имеются зачатки их назревания.

Целью статьи является анализ современных внутриорганизационных технологий разрешения конфликтов.

Объект исследования - современные технологии разрешения конфликтов.

Существует довольно много видов внутриорганизационных конфликтов, но нами рассматриваются именно противоречия, возникающие в коллективах. В статье проанализированы технологии разрешения конфликтов в двух проекциях: в разрешении возникшего конфликта и в его предотвращении.

\section{Методы исследования.}

В качестве методов исследования были использованы следующие:

- теоретический анализ научных источников;

- анализ зарубежных методик разрешения конфликтов.

Современные технологии разрешения конфликтов ориентированы на конструктивное участие всех сторон конфликта. При этом, определенную роль играют действия руководителей, поскольку они наделены исключительными функциями по управлению конфликтами внутри своего подразделения и несут персональную ответственность за обстановку в коллективе.

Безусловно, для предотвращения противоречий необходимо применять предупреждающие методы. В случае, если конфликт все-таки образовался по разным причинам: либо противоречие было неявным, либо этому вопросу не уделялось должного внимания - необходимо руководствоваться иными методиками. В любом случае, разрешение внутриорганизационных конфликтов в коллективе должно быть ориентировано на психологический аспект сотрудников. То есть необходимо проводить работу с каждым сотрудником, уделять внимание его потребностям и интересам.

\section{Заключение}

В данной статье изучены основные современные методы по предупреждению конфликтов и их разрешению, применяемые во многих организациях. Рассмотрены теоретические аспекты внутриорганизационных конфликтов, в том числе динамика конфликта, его структура, и их типология. Также составляющей статьи является ориентация на типичные ошибки руководителей при разрешении конфликтов.

Ключевые слова: внутриорганизационный конфликт, конфликт в коллективе, технологии разрешения конфликтов, управленческое воздействие, медиация.

Gautas 20210524

Priimtas 20210610 